\title{
Factors Affecting Financial Reporting through the Internet (Internet Financial Reporting) in the Company's Website (Literature Study)
}

\author{
Audrey M. Siahaan ${ }^{\# 1}$, Hesti Arwi Waruwu ${ }^{* 2}$, Victor H. Sianipar ${ }^{\# 3}$, Oloan Simanjuntak ${ }^{\# 4}$

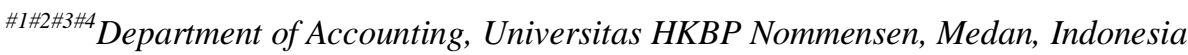

Abstract

The use of the internet in the business world has influenced the traditional form of presenting corporate information. In addition, the rapid development of the internet creates new ways for companies to communicate with investors. Companies use the internet to report financial information to investors, known as Internet Financial Reporting (IFR). Disclosure of data on the company's website is a signal from the company to outside parties, one of which is reliable financial information and will reduce uncertainty about the company's prospects.

This article examines the effect of firm size, profitability, liquidity, type of industry, leverage, auditor reputation, age of listing, level of public ownership, and level of foreign ownership on the probability of companies implementing Internet Financial Reporting (IFR). The data used in this study is secondary data in the form of data from non-financial companies listed on the Indonesia Stock Exchange.

The conclusion that can draw from this article is that the variables of profitability, firm size, liquidity, type of industry, auditor reputation, foreign ownership, and public ownership have a positive and significant effect on financial reporting practices via the internet (Internet Financial Reporting). While the leverage variable, listing age, was not proven to substantially impact financial reporting practices via the internet (Internet Financial Reporting).

Keywords - Financial Reporting, Internet Financial Reporting.

\section{INTRODUCTION}

The development of technology in the current era of globalization is substantial. The product of the business world looks more advanced in every country, including the State of Indonesia, which is required to adapt to these developments and changes.

Environmental developments also contribute to the business world. Environmental outcomes will lead to competitive competition in the business world and changing economic and ecological conditions. The rapid growth of technology makes the internet a new alternative for companies to present information about companies financially and non-financially.

The existence of technology is used because it is more effective in helping the needs of the company. Based on the use of internet media to obtain financial information, supporting media for the presentation of financial statements emerged, namely financial reporting via the internet.

Financial statements are one of the basics in making investment decisions for investors. Economic announcements contain information that can influence investor reactions. Investors and investment managers are closely related to the risks and returns of developing their investments. The parties concerned need information in making decisions to buy, hold and sell the asset. 
DOI: $\underline{10.51386 / 25815946 / \mathrm{ijsms}-\mathrm{v} 4 \mathrm{i} 4 \mathrm{p} 101}$

Volume: 4 Issue: 4

July to August 2021

https://www.ijjsmsjournal.org

Most of the companies have benefited from internet users. With the internet, the company's financial information will be easily accessible to users due to geographical barriers. In addition, the internet also offers various conveniences to companies in terms of access, cost savings for printing and distributing financial reports. Internet users to report financial information is called Internet Financial Reporting (IFR).

Financial reports, which are usually printed, through the internet, the company's financial statements can be distributed more quickly (timeliness aspect), meaning that with internet media companies are able to exploit the use of this technology to be more open (transparency aspect) and to inform their financial statements (disclosure aspect) more timely.

Stakeholders need fast, easy and accurate information as consideration for making decisions. Website is one of the media to present information more quickly, efficiently, and accurately. Therefore, this research is essential to make it easier for investors to know the company's performance to invest their shares in IFR companies (Internet Financial Reporting). Managerial ownership is the proportion of company stock ownership owned by management.

Business entities, especially companies that have made public offerings (go public), face the condition to be more transparent in disclosing company information. Disclosure of such transparent information will further assist in decision-making in anticipating increasing changing economic needs.

The primary purpose of using Internet Financial Reporting (IFR) related to investor relations is to provide comprehensive and timely information to individual investors that were previously only available to specific groups such as institutional investors and analysts.

The internet is used as a medium for delivering important information. The internet has various advantages such as pervasiveness, border lessens, real-time, low cost, high interaction, and integration with text, numbers, images. Animation, video, and sound.

The company can be used as a distinct advantage because the internet is used as a medium in providing information to stakeholders regarding the description of the company's condition, financial news, and so on through the company website. That way, interested parties can access it globally and in real-time wherever they are without waiting or contacting the company.

The financial information presented in the IFR includes comprehensive financial statements, including footnotes, financial statement sections, financial highlights, and summary financial statements. In addition, the dissemination of financial information through the internet can also attract investors and provide a good image for the company.

Based on the results of a survey conducted by APJII (Association of Indonesian Internet Service Providers) in 2019 , the number of internet users increased by $73.7 \%$ compared to 2018 , which was $64.8 \%$. In 2018 the number of Indonesian internet users reached 171.17 million users. It means that there is an $8.9 \%$ increase in growth from 2018 to 2019-2020 (Q2).

The company's website has become the most widely used and necessary source of information for stakeholders, and the web is a unique medium for presenting financial and non-financial information all the time.

Financial reporting on the internet aims as a communication medium, especially for investors who need financial statements as consideration for investors. In addition, disclosing the information using internet media can make it easier for investors to assess its performance by accessing its website.

Disclosure of financial reporting through the website has now developed as the fastest and most effective medium in conveying matters relating to the company.

Publication of financial reporting using the internet is still voluntary. IFR is because there are no regulations that regulate more specifically regarding the publication of financial statements through the internet. As a result, some companies only disclose part of their financial reporting, while others make complete 
DOI: $\underline{10.51386 / 25815946 / \mathrm{ijsms}-\mathrm{v} 4 \mathrm{i} 4 \mathrm{p} 101}$

Volume: 4 Issue: 4

July to August 2021

https://www.ijjsmsjournal.org

disclosures on company-owned websites. As a result, there are differences in the quality of information revealed between one company and another, so that later it can influence stakeholder decision making.

Who can access the information presented on the company's website at a cheaper, faster, and accurate cost? Internet Financial Reporting (IFR) can effectively deliver information to customers, investors, and shareholders. Internet Financial Reporting (IFR) is an internet-based financial reporting disclosure presented to investors, creditors, and external parties on their respective company websites.

The size of the company also determines the level of experience in its relationship with investors. Companies with ample experience in dealing with investors will tend to be more interested in conducting financial reporting by utilizing internet technology as a new tool to communicate with existing investors and attract investors. The larger the size of the company, the greater the number of shares outstanding.

Stakeholders need fast, easy and accurate information as consideration for making decisions. Website is one of the media to present information more quickly, efficiently, and accurately. Therefore, this research is essential to make it easier for investors to know the company's performance to invest their shares in IFR(Internet Financial Reporting).companies .

Corporate governance mechanisms are implemented to control agency problems and ensure the behavior of managers is in line with the interests of shareholders. Therefore, managers who are also shareholders will have a lot of motivation to increase the company's value, which will be the welfare of management as shareholders and shareholders by disseminating financial statement information via the internet.

The practice of IFR is part of agency theory.. Within the agency theory framework, there are three kinds of agency relationships:

- $\quad$ Agency relationships between managers and owners

- $\quad$ Agency relationships between managers and creditors

- $\quad$ Agency relationships between managers and the government

The relationship between agency theory arises when one party (principal) pays another party (agent) to perform services and delegates decision-making authority to the agent.

Within the company's scope, the company's owner is the principal, and the company's management is the agent. Owners pay management and expect management to act in the interests of the owners of the company.

The use of a reputable Public Accounting Firm (KAP) is a positive signal because the public considers the company to have information that is not misleading and has disclosed the information as transparently as possible. It will increase the company's image and believe that the information in the company's financial statements can be trusted and encourage companies to disseminate their financial statements, one of which is through the company's website or Internet Financial Reporting.

Agency theory is concerned with efforts to solve problems that arise in agency relationships. The separation of ownership and control increases information asymmetry between managers and principals, where managers must provide better information on current and future company performance than the principal does.

\section{Problem Formulation and Problem Limitation}

To formulate the problem as follows: "How is the Effect of Financial Reporting through the Internet (Internet Financial Reporting) on the Website of Companies listed on the Indonesia Stock Exchange (IDX)

Based on identifying the problem, we can conclude that the purpose of research in compiling a thesis is to determine the effect of financial reporting through the internet (Internet Financial Reporting) on the Company's Website.

\section{III.LITERATURE REVIEW}

Agency theory makes a contractual model between two or more people (parties) where one party is called the agent and the other party is called the principal. For example, company management is an agent and principal shareholder who is interested in their ownership of the company. Management will make decisions that will maximize its claims, but these decisions are different from decisions needed to maximize shareholders' interests. 
DOI: $\underline{10.51386 / 25815946 / \mathrm{ijsms}-\mathrm{v} 4 \mathrm{i} 4 \mathrm{p} 101}$

Volume: 4 Issue: 4

July to August 2021

https://www.ijjsmsjournal.org

The practice of internet financial reporting (IFR) is a medium to convey information as required in the agency contract. A relationship between the principal and the agent makes the company's management disclose financial statements to shareholders. Financial statements are a means of accountability of management to owners. So as a form of responsibility, the agent will try to fulfill all the principal's wishes.

In aligning the interests between managers and shareholders, the company should increase transparency and disclosure of company information. Financial statements are considered a medium of management accountability to owners. Wide disclosure in the company's financial statements is expected to reduce information asymmetry and monitor management performance

Financial statements are the object of analysis of financial statements. Therefore, understanding the background of the preparation and presentation of financial statements is essential before analyzing the financial statements themselves. Disclosure of investors for the main interest of investors is to estimate the level of probability and cash flows of the company in the future, and financial forecasts are relevant information for investors.

Signal theory is a behavior of company management in guiding investors regarding management's view of the company's prospects for the future. In addition, signal theory can assist companies in fully disclosing information by utilizing internet media to improve the quality of company disclosures. Reporting financial statements through internet media or what is known as Internet Financial Reporting can assist companies in disseminating positive signals in the form of information regarding the company's advantages, which aims to attract potential investors. So Internet Financial Reporting is considered a positive means of communication to the broader community.

\section{Finance report}

The factors of Financial Reporting through the Website are as follows: Internet Financial Reporting (IFR), Company Size, Company Profitability, Company Liquidity, Type of Industry, Company Leverage, Auditor Reputation, Listing Age, Public Ownership, Foreign Ownership.

Internet Financial Reporting is a way for companies to include their financial statements via the internet, namely through its website. However, large companies have high agency costs because large companies have a more outstanding obligation to submit complete and fast financial reporting to shareholders as management accountability. In addition, the log of market capitalization is more representative than the log of total assets, especially for companies that go public (Marston and Polei 2004 and Oyelere et al. 2003).

Large companies have complete and complex management information systems, so these companies can provide better information, including using internet facilities to include the company's financial statements. In addition, it is easier for large companies to monitor their activities in the capital market and the social environment in general, thus putting pressure on companies to carry out more complete and broad reporting practices, one of which is IFR practices. Therefore, the size of the company influences the company's decision to implement IFR practices.

Investors will assess the performance of management in managing a company can use profitability. Profitable companies will have a stronger incentive to disseminate company information, especially financial information. ROA has a more independent level in measuring profitability than ROE (Oyelere et al., 2003).Profitability is the company's ability to generate profits within a certain period. Companies with high profitability will tend to disclose more details about their activities or disclose more information to potential users through IFR. As a result, companies with high profitability will attract the attention of investors with more complete and extensive financial reporting using IFR. In addition, companies with good financial performance try to disseminate good company news, one of which is by using IFR. Thus the company's profitability influences the company's decision to implement IFR practices.

Investors to see the company's ability to pay off short-term obligations will use liquidity. The higher the company's ability to pay off its short-term debt, the more liquid the company is. Where the level of company liquidity will affect investors in making investment decisions, investors will not invest in less liquid companies because they will assume that less liquid companies tend to go bankrupt. The ratio of current assets to current debt (current ratio) is widespread in measuring company liquidity (Oyelere et al., 2003). 
DOI: $\underline{10.51386 / 25815946 / i j s m s-v 4 i 4 p 101}$

Liquidity shows the company's ability to pay its short-term obligations. The company's strength indicated by a high liquidity ratio will relate to the company's financial reporting as complete and broadly as possible. Companies with a high level of liquidity will tend to be motivated to inform their financial statements as completely and widely as possible compared to companies with a low level of liquidity. Thus, the company's liquidity level influences the company's decision to implement IFR practices. In the face of change in technology, the internet is one of the new technologies in corporate financial reporting. Companies belonging to industries that use a high level of technology (manufacturing) generally want to show their technological awareness through IFR to attract investors and debtors. Thus, the type of industry influences the company's decision to implement IFR practices.

In general, industries with high complexity tend to follow the times in running their business. One way to do this is to use technology currently developing, namely the internet, as a medium for financial reporting and growing interactions between companies and the environment. The more complex the industry, the higher the company's desire to present its financial reports more transparently

Leverage is the company's ability to pay off its current liabilities. Agency theory explains that the higher the company's leverage, the better the transfer of wealth from creditors to company shareholders. Therefore, companies with a more significant proportion of debt in their capital structure will have higher agency costs. Leverage is the company's ability to meet its long-term obligations. Companies with a high level of leverage will tend to use IFR to help disseminate positive company information to attract the attention of creditors and shareholders, not to focus too much on high leverage companies. Therefore. The company's leverage level influences the company's decision to implement IFR practices.

The company will give a positive signal regarding the information provided to shareholders by using a reputable public accounting firm. A reputable Public Accounting Firm will provide information that is not misleading and report its financial information more transparently.. The company's image will improve through IFR. IFR will make investors trust the company because they can trust the company's financial statements. The use of a reputable KAP by the company will be interpreted by the public as a trustworthy company, especially about the company's financial performance. In addition, companies that use reputable KAPs (Big Four) will report company information transparently to attract creditors and investors. Thus, increase the company's image among the public. Thus, the auditor's reputation influences the company's decision to implement IFR practices.

Companies listed on the Indonesia Stock Exchange (IDX) tend to make their financial reporting more transparent than companies that have not listed on the IDX. The companies that have not listed on the IDX have more experience in publishing their financial statements. The more experienced company will carry out financial reporting by the times. Not only in a paper-based reporting system but also in a paperless reporting system. The company's listing age is measured by using the difference between the year of observation of the financial statements and the initial public offering (IPO).Companies listed on the Indonesia Stock Exchange (IDX) will carry out complete financial reporting than companies that are not listed on the IDX. In addition, companies that have long been listed on the IDX will tend to change the method of reporting financial information by technological developments to attract investors, one of which is through IFR. Thus, the age of the company's listing influences the company's decision to implement IFR practices.

Public ownership or the proportion of share ownership by the public is the number of company shares owned by the people, namely individuals or institutions with share ownership below 5\% who are outside management and have no special relationship with the company. Share ownership is intended for shares traded, not for claims that are owned or held forever. Public Ownership is measure by using the percentage of shares owned by the public to the company's total shares. Public Ownership shared whose Ownership is below 5\% where the stakes are traded (trading). The Ownership of the claims only intended for short-term profits. Public Ownership is the percentage of share ownership owned by the public to the total number of shares in the company. The greater the composition of the company's Ownership by the public will trigger the disclosure of company information more broadly, one of which is disclosing the company's financial statements through IFR. The users of financial statements are not only internal parties of the company but also the public. Thus, public Ownership has an influence on company decisions in implementing IFR practices. 
DOI: $\underline{10.51386 / 25815946 / \mathrm{ijsms}-\mathrm{v} 4 \mathrm{i} 4 \mathrm{p} 101}$

Foreign Ownership is the percentage of shares owned by foreign parties to the total number of shares in the company. Companies with foreign Ownership will tend to make more comprehensive disclosures, one of which is by implementing IFR because users of financial statements are not only in the country but also abroad. With the implementation of IFR, users of the financial statements of companies abroad can access the financial statements quickly. Thus, foreign Ownersh Foreign Ownership or the proportion of share ownership by foreign parties is the number of company shares owned by foreign parties. Foreign Ownership is measure by using the percentage of shares held by foreign parties to the company's total shares.ip has an influence on company decisions in implementing IFR practices.

\section{Internet Financial Reporting (IFR)}

The use of the internet makes financial reporting's company more accessible and faster to be accessed by anyone, anytime, and anywhere. The internet can also make the presentation of financial information more cost-effective because companies do not need to incur costs for printing financial reports or distributing financial statements that are not in one geographic area. The index used to measure IFR (Internet Financial Reporting) consists of four components: content, timeliness, technology utilization, and user support.

Internet Financial Reporting (IFR) is a method used by companies to publish and disseminate their financial reports through internet media such as its website. Companies use Internet Financial Reporting (IFR) to establish better and faster communication with stakeholders, especially investors. Information presented on the company's website can be accessed by anyone, anytime and anywhere, at a lower cost.

The Steering Committee of the Business Reporting Research Project (FASB, 2000) provides several corporate motives for presenting information via the internet:

1. Reduced printing costs and posting of annual reports.

2. More complete access than a traditional practice.

3. Provide up-to-date information.

4. Speeding up the time in the distribution of information.

5. Establishing communication with previously unidentified consumers.

6. Adding to conventional disclosure practices.

7. Increase the amount and data disclosed.

8. Improve access to potential investors for small companies.

\section{IV.METHODOLOGY}

The type of research used in this article is a qualitative method with a descriptive approach or literature study in data collection. The literature study used in this study is previous research that discusses financial reporting via the internet (internet financial reporting) on the company's website.

The data analysis method uses a descriptive qualitative approach through literature review, namely by describing research results on factors that affect Internet Financial Reporting on the Company's Website.

\section{RESEARCH RESULTS AND DISCUSSION}

This article summarizes as many as 19 articles sourced from research where the research object is companies listed on the Indonesia Stock Exchange. Of the 19 papers summarized, several articles focus more on the factors that influence the disclosure policy of financial statements on the company's website. However, several articles examine the nature and extent of financial reporting on the company's website as an instrument that connects stakeholders.

From these 19 articles, it is known that $90 \%$ of manufacturing companies listed on the Indonesia Stock Exchange (IDX) have included financial reports on the company's website. Table 1 is a summary of research results from 19 articles that were used as study material. 
Table 1.

Summary of 19 Articles About Internet Financial Reporting

\begin{tabular}{|c|c|c|c|}
\hline No & Researcher & $\begin{array}{c}\text { Research Title } \\
\end{array}$ & Result \\
\hline 1 & $\begin{array}{l}\text { Oktavia, EgaDastentya. } \\
\text { (2015) }\end{array}$ & $\begin{array}{l}\text { Analysis of Factors Affecting Corporate } \\
\text { Reporting Through the Internet. }\end{array}$ & $\begin{array}{l}\text { The results of this study indicate that company size has } \\
\text { a positive and significant effect on internet financial } \\
\text { reporting }\end{array}$ \\
\hline 2 & $\begin{array}{l}\text { Marston, C. And A. } \\
\text { Polei. (2004). }\end{array}$ & $\begin{array}{l}\text { Corporate Reporting on The Internet by } \\
\text { German Companies }\end{array}$ & $\begin{array}{l}\text { The results of this study indicate that the profitability of } \\
\text { the company has a positive and significant effect on } \\
\text { providing good news on the company's financial } \\
\text { reporting. }\end{array}$ \\
\hline 3 & Marwati, Sofa. (2016) & $\begin{array}{l}\text { Analysis of Factors Affecting Internet } \\
\text { Financial Reporting }\end{array}$ & $\begin{array}{l}\text { The results show that profitability has a positive impact } \\
\text { on the company's financial reporting }\end{array}$ \\
\hline 4 & $\begin{array}{l}\text { ArdiMurdokoSudarma } \\
\text { djidan Lana Sularto. } \\
(2007)\end{array}$ & $\begin{array}{l}\text { The Influence of Company Size, } \\
\text { Profitability and Type of Company } \\
\text { Ownership on the Area of Voluntary } \\
\text { Disclosure of Annual Financial } \\
\text { Statements. }\end{array}$ & $\begin{array}{l}\text { The results showed that profitability is a performance } \\
\text { indicator carried out by management in managing the } \\
\text { company's wealth as indicated by the profit generated. } \\
\text { Therefore, companies with high profitability seen as } \\
\text { having good performance because they can manage } \\
\text { company assets well. }\end{array}$ \\
\hline 5 & $\begin{array}{l}\text { Hanny Sri Lestari } \\
\text { danAnisChariri. (2009) }\end{array}$ & $\begin{array}{l}\text { Analysis of Factors Affecting Internet } \\
\text { Financial Reporting }\end{array}$ & $\begin{array}{l}\text { The results of this study indicate that liquidity has a } \\
\text { positive and significant influence on financial reporting } \\
\text { through internet financial reporting. }\end{array}$ \\
\hline 6 & $\begin{array}{l}\text { Prasetya, } \\
\text { MellisadanSoniAgusIr } \\
\text { wandi. (2012) }\end{array}$ & $\begin{array}{l}\text { Factors Affecting Financial Reporting } \\
\text { Through the Internet (Internet Financial } \\
\text { Reporting). }\end{array}$ & $\begin{array}{l}\text { The results of this study indicate that the age of the } \\
\text { listing does not affect financial reporting through } \\
\text { internet financial reporting. }\end{array}$ \\
\hline 7 & $\begin{array}{l}\text { Arum } \\
\text { PrastiwidanAyuPuspita } \\
\text { ningrum. (2013) }\end{array}$ & $\begin{array}{l}\text { Disclosure of Company Characteristics on } \\
\text { Disclosure of Internet Financial and } \\
\text { Sustainability Reporting (IFRS) (Study on } \\
\text { Companies Listed on the Indonesia Stock } \\
\text { Exchange) }\end{array}$ & $\begin{array}{l}\text { The results of this study indicate that the type of } \\
\text { industry has a positive effect on financial reporting } \\
\text { through internet financial reporting. }\end{array}$ \\
\hline 8 & Weli. (2017) & $\begin{array}{l}\text { The company's internal characteristics and } \\
\text { mandatory disclosure size of web-based } \\
\text { financial reporting }\end{array}$ & $\begin{array}{l}\text { These results indicate that the type of industry has a } \\
\text { positive and significant effect on financial reporting } \\
\text { through internet financial reporting. }\end{array}$ \\
\hline 9 & $\begin{array}{l}\text { I } \\
\text { GustiAyuRatihPermata } \\
\text { Dewi,IKetutYadnyana, } \\
2017 .\end{array}$ & $\begin{array}{l}\text { The Influence of Profitability and } \\
\text { Company Size on Timeliness of Financial } \\
\text { Report Submission and Its Implications on } \\
\text { Earnings Response Coefficient. }\end{array}$ & $\begin{array}{l}\text { The results of this study indicate that public ownership } \\
\text { has a positive and significant effect on financial } \\
\text { reporting through internet financial reporting }\end{array}$ \\
\hline 10 & $\begin{array}{l}\text { Agboola, } \\
\text { AyodejiAkinloludanSa } \\
\text { lawu, Mary Kehinde. } \\
(2012)\end{array}$ & $\begin{array}{l}\text { The Determinants of Internet Financial } \\
\text { Reporting: Empirical Evidence from } \\
\text { Nigeria. }\end{array}$ & $\begin{array}{l}\text { The results show that the auditor's reputation has a } \\
\text { positive effect on financial reporting through internet } \\
\text { financial reporting. }\end{array}$ \\
\hline 11 & Aly .(2009) & $\begin{array}{l}\text { The Influence of Profitability Rank, } \\
\text { Company Size, Public Ownership, } \\
\text { Leverage, and Industry Groups on Internet } \\
\text { Financial Reporting (IFR) Levels. }\end{array}$ & $\begin{array}{l}\text { The results show that foreign ownership does not affect } \\
\text { financial reporting through internet financial reporting. }\end{array}$ \\
\hline 12 & $\begin{array}{l}\text { Maulana,Muhammad } \\
\text { Iqbal. } 2017 .\end{array}$ & $\begin{array}{l}\text { Analyst of Factors Affecting Internet } \\
\text { Financial Reporting at Regional } \\
\text { Development Banks and Commercial } \\
\text { Banks. }\end{array}$ & $\begin{array}{l}\text { This study indicates that the related factors in internet } \\
\text { financial reporting have a positive and negative } \\
\text { influence depending on the company's system. }\end{array}$ \\
\hline 13 & $\begin{array}{l}\text { Nuarisa, Adriana. } \\
2017 .\end{array}$ & $\begin{array}{l}\text { Analysis of Factors Affecting Internet } \\
\text { Financial Reporting in Indonesia's } \\
\text { Property \& Real Estate Sector with } \\
\text { Financial Performance Moderating } \\
\text { Variables. }\end{array}$ & $\begin{array}{l}\text { This study indicates that the related factors in internet } \\
\text { financial reporting have a positive and negative } \\
\text { influence depending on the company's system. }\end{array}$ \\
\hline
\end{tabular}


DOI: $\underline{10.51386 / 25815946 / \mathrm{ijsms}-\mathrm{v} 4 \mathrm{i} 4 \mathrm{p} 101}$

Volume: 4 Issue: 4

July to August 2021

https://www.ijjsmsjournal.org

Table 1.(Continued)

Summary of 19 Articles About Internet Financial Reporting

\begin{tabular}{|c|c|c|c|}
\hline No & Researcher & Research Title & Result \\
\hline 14 & $\begin{array}{l}\text { Andriyani, R., } \\
\text { \&Mudjiyanti, R. } \\
\text { (2017). }\end{array}$ & $\begin{array}{l}\text { The Influence of Profitability, Leverage, } \\
\text { Number of Independent Commissioners } \\
\text { and Institutional Ownership on Disclosure } \\
\text { of Internet Financial Reporting (IFR) on } \\
\text { the Indonesia Stock Exchange. }\end{array}$ & $\begin{array}{l}\text { The results of this study have a positive influence on } \\
\text { companies that have websites on internet financial } \\
\text { reporting. }\end{array}$ \\
\hline 15 & $\begin{array}{l}\text { Ayuningtias, D., } \\
\text { \&Khairunnisa. (2019). }\end{array}$ & $\begin{array}{l}\text { Factors that Determine the Application of } \\
\text { Internet Financial Reporting (Case Study } \\
\text { on Mining Sector Companies listed on the } \\
\text { Indonesia Stock Exchange (IDX) 2013- } \\
\text { 2017) }\end{array}$ & $\begin{array}{l}\text { This study indicates that the related factors in internet } \\
\text { financial reporting have a positive and negative } \\
\text { influence depending on the company's system. }\end{array}$ \\
\hline 16 & Ginting, W. A. (2018). & $\begin{array}{l}\text { Logistics Regression in Analyzing Factors } \\
\text { Affecting Financial Reporting Through the } \\
\text { Internet. }\end{array}$ & $\begin{array}{l}\text { This study indicates that the related factors in internet } \\
\text { financial reporting have a positive and negative } \\
\text { influence depending on the company's system. }\end{array}$ \\
\hline 17 & M.Riduan.2015 & $\begin{array}{l}\text { Effect of Profitability, Leverage, } \\
\text { Blockholder Ownership and Auditor's } \\
\text { reputation on Internet Financial Reporting. }\end{array}$ & $\begin{array}{l}\text { The results of the study show that it has a positive effect } \\
\text { on internet financial reporting. }\end{array}$ \\
\hline 18 & Chariri\&Lestari .2005 & $\begin{array}{l}\text { Analysis of Factors Affecting Financial } \\
\text { Reporting Through the Internet (Internet } \\
\text { Financial Reporting) on the Company's } \\
\text { Website. }\end{array}$ & $\begin{array}{l}\text { This study indicates that the related factors in internet } \\
\text { financial reporting have a positive and negative } \\
\text { influence depending on the company's system. }\end{array}$ \\
\hline 19 & $\begin{array}{l}\text { Suripto, Bambang. } \\
2006 .\end{array}$ & $\begin{array}{l}\text { The Influence of Quantity, Profitability, } \\
\text { Share Ownership by the Public, and } \\
\text { Industry Groups on the Level of } \\
\text { Disclosure of Financial Information on the } \\
\text { Company's Website }\end{array}$ & $\begin{array}{l}\text { The results of this study indicate that the profitability of } \\
\text { good results on internet financial reporting. }\end{array}$ \\
\hline
\end{tabular}

According to Oktavia, EgaDastentya (2015) states that the larger the company's size, the more financial and non-financial information' disclosed on the website. The effect of company size on internet financial reporting is a positive effect on internet financial reporting. And on average, companies listed on the Indonesia Stock Exchange apply internet financial reporting as financial reporting.

According to Marston, C. And A. Polei. (2004) stated that a company with good performance and profitability would increasingly enable the company to practice IFR (Internet Financial Reporting) to disseminate good news. Marwati and Sofa, 2016 said that the results of profitability research had a positive and significant effect on financial reporting in internet financial reporting. Return on Assets (ROA) reflects the rate of return on all assets owned by the company. The higher the ROA value, the better the company's financial performance so that it demonstrates the company is in good condition.

According to Hanny Sri Lestari and AnisChariri (2009), liquidity is the company's ability to pay off short-term obligations. The higher the company's ability to pay off its short-term debt, the more liquid the company is. Companies will disclose more information if their liquidity ratio is high to differentiate themselves from other companies with less favorable liquidity. So, companies with high liquidity are more likely to update their financial statements and practice IFR. Information about the company's high liquidity is known to many parties. The relationship between liquidity and IFR is that the higher the liquidity, the higher the disclosure of information submitted in the financial statements on the company's website. Signal theory arises because companies with high liquidity tend not to give signals by not practicing IFR. After all, financial reporting through a company's website is voluntary, so managers do not focus on it.

According to Hanny Sri Lestari and AnisChariri (2009) stated that: Along with increasing leverage, managers can use IFR (Internet Financial Reporting) to help disseminate positive company information to creditors and shareholders' so as not to focus too much on high corporate leverage. . This is because financial reporting through the internet can contain more company information than through paper-based reporting. Companies with high or low leverage will still present company financial information to show management openness which is a positive image. The exposure carried out by the management is expected to generate the trust of the stakeholders. This reason makes companies ignore the level of leverage in making decisions on presenting information on the internet. 
DOI: $\underline{10.51386 / 25815946 / \mathrm{ijsms}-\mathrm{v} 4 \mathrm{i} 4 \mathrm{p} 101}$

According to Prasetya, Mellisa, and SoniAgusIrwandi (2012) stated that a company with a long life is not a guarantee that the company will have competent human resources in the field of technology implement financial reporting via the internet. Listing age has no effect on financial reporting via the internet (internet financial reporting). All companies on the Indonesia Stock Exchange are required to perform financial reporting via the internet. Of course, these companies are trying to improve the quality of reporting via the internet (internet financial reporting) regardless of the age of the company listing on the Indonesia Stock Exchange.

According to Arum Prastiwi and AyuPuspitaningrum (2013), disclosure of financial information on the internet may differ between industries. In general, industries with high complexity tend to follow the times in running their business. Weli (2017) states that: companies that use high technology prefer to use the internet to disclose their financial information.

According to I GustiAyuRatihPermataDewi, I KetutYadnyana (2017) states that public ownership is the number of shares owned by the public in a company, namely individuals or institutions whose share ownership is less than five percent. This shared ownership does not aim to be owned or held forever but aims to buy and sell. Increasingly widespread public ownership will require companies to disseminate information about companies more transparently. In addition, public ownership domiciled in various geographic areas will increase the need for fast and accurate information to consider shareholders in making decisions. Thus, companies with dispersed public ownership tend to encourage managers to implement Internet Financial Reporting to reduce agency conflicts and reach all their shareholders.

According to Agboola, AyodejiAkinlolu, and Salawu, Mary Kehinde (2012) stated that: auditor reputation affects Internet Financial Reporting (IFR).A large public accounting firm will be able and willing to disclose all the problems that exist in the company to become meaningful information for investors. It is what makes investors believe in companies that consider the auditor's reputation by using the services of a highly reputable public accountant so that the financial statements that we attach to the company's website are more investors who want to join the company.

According to Aly (2009), foreign share ownership is better able to control management policies because it has good capabilities, so it has a significant effect on the implementation of IFR. This inconsistent result is caused by the measurement of foreign ownership only looking at the percentage of foreign shares that are likely to be combined with the percentage of investors' shares from Indonesia.

In 2018 - 2019, manufacturing companies listed on the IDX concluded that profitability, liquidity, company size, public ownership, foreign ownership, auditor reputation. And the type of industry has a positive and significant impact on implementing financial reporting through internet financial reporting (IFR). In contrast, leverage and age of listing have no positive and significant effect on financial reporting through internet financial reporting (IFR).

\section{VI.CONCLUSIONS AND SUGGESTIONS}

The literature review results show that several factors affect Financial Reporting Through Internet Financial Reporting (IFR), namely company size, profitability, type of industry, leverage, Foreign ownership, Public Ownership, Listing Age, Auditor reputation, and Liquidity.

The next researcher discusses the literature on IFR by looking at variables outside of the manufacturing sector, such as the Raw Materials Income sector, the Service Sector, to conduct Internet Financial Reporting. Increasing the influence of each internet financial reporting factor for companies that already have a website. Financial statements that are clear and easy to understand will attract investors to the company.

\section{REFERENCES}

[1] Craven, B. M. and Marston, C.L.1999 Financial Reporting on the Internet by Leading UK Companies. European Accounting Review. Volume 8, No. 2, 1999, pp 321-333

[2] Pichegger\&Wagenhoger.1999,.Lai .et al. .2010 .PengaruhIntrernet Financial Reporting dan Tingkat PengungkapanInformasi Website TerhadapFrekuensiTerdaftar di BEI 
DOI: $\underline{10.51386 / 25815946 / i j s m s-v 4 i 4 p 101}$

Volume: 4 Issue: 4

July to August 2021

https://www.ijsmsjournal.org

[3] Ettredge, et. al.2002 .Pengaruh Internet financial Reporting, $\quad$ Tingkat PengungkapandanKetepatanWaktuapenyampaianInformasiKeuangan WebsiteTerhadapHargaSahamStudiEmpirisPada Perusahaan Yang Listing di JII Periode 2008-2012

[4] Debreceny, R., G.L. Gray and A. Rahman, "The Determinants of Internet Financial Reporting," Journal of Accounting and Public Policy 21, (2002), pp. 371-394., et. al. 2007.

[5] Ismail, Tariq H. 2002. "An Empirical Investigation of Factors Influencing Voluntary Disclosure of Financial Information on the Internet in the GCC Countries". Working Paper Series. July 2002

[6] Chariri\&Lestari .2005.AnalisisFaktor- factor yang MempengaruhiPelaporanKeuanganMelaluiInternet (Internet Financial Reporting) dalam Website Perusahaan

[7] Suripto, Bambang. 2006. "PengaruhBesaran, Profitabilitas, PemilikanSahamolehPublik, danKelompokIndustriterhadap Tingkat PengungkapanInformasiKeuangandalam Website Perusahaan”. JurnalAkuntansidanKeuangan, vol. 5, No.1, hal 1- 27.

[8] Abdelsalam, O.H., \& Street, D.L. 2007 . Corporate governance and the timeliness of corporateinternet reporting by U.K. listed companies. Journal of InternationalAccounting, Auditingand Taxation, 16, 111-130.

[9] Andrikopoulos, Andreas. 2007. "Financial Reporting Practices On The Internet: The Case Of Companies Listed In The Cyprus Stock Exchange". Panteion University of Social and Political Sciences, Department of International and European Studies, Athens, Greece.

[10] Ezat\&El, Masry. 2008 . AnalisisFaktor-faktor yang MempengaruhiKetepatanWaktu Corporate Internet Reporting pada Perusahaanperusahaan yang Terdaftar di Bursa Efek Indonesia

[11] Candra .2008 .Analisis- Faktor-faktor yang MempengaruhiKetepatanWaktu Corporate Internet reporting pada Perusahaan-perusahaan yang Terdaftar di Bursa Efek Indonesia

[12] Aly . 2009 . PengaruhRingkatProfitabilitas, Ukuran Perusahaan, KepemilikanSahamOlehPublik, Leverage danKelompokIndustriTerhadap Tingkat Internet Financial Reporting (IFR) JurnalComputech\&Bisnis, Vol. 6, No. 2.

[13] Fitriana . 2009 . PengaruhUkuran Perusahaan, Profitabilitas, Leverage, danLikuiditasTerhadapPraktikPengungkapan Internet Financial Reporting (IFR), (StudiEmpiris Perusahaan Manufaktur yang Terdaftar di Bursa Efek Indonesia tahun 2015-2016)

[14] Ashbaugh, H., K. Johnstone, and T. Warfield. (1999). Corporate Reporting on the Internet. Accounting Horizons Volume 13, No. 3 , 1999, pp 241-257.

[15] Marston, C. and Polei, A. 2004. “Corporate reporting on the internet by German companies”. International Journal ofAccounting Information Systems, Vol. 5, pp. 285-311

[16] MellisaPrasetya\&SoniAgusIrwandi .2012.“Faktor-faktor yang MempengaruhiPelaporanKeuanganMelaui Internet (Internet Financial Reporting) pada Perusahaan Manufaktur di Bursa Efek Indonesia”. The Indonesian Accounting Review, Vol. 2, No. 2, Juli, hlm. 151158

[17] Luciana Spica Almilia. 2008.Faktor-faktor yang MempengaruhiPengungkapanSukarela "Internet Financial and Sustainability Reporting”. Surabaya:STIEPerbanas. JurnalAkuntansidan Auditing Indonesia, Vol. 12, No. 2, Desember 2008, hlm. 97-107

[18] Weli. (2017). The company's internal characteristics and mandatory disclosure size of web-based financial reporting. Journal of Economics, Business, and Accountancy Ventura. Volume 19, No. 3, 2017, pp 435-446

[19] Andriyani, R., \&Mudjiyanti, R. (2017). Pengaruh Tingkat Profitabilitas, Leverage, JumlahDewanKomisarisIndependendanKepemilikanInstitusionalTerhadapPengungkapan Internet Financial Reporting (IFR) di Bursa Efek Indonesia. Journal of Chemical Information and Modeling,15(1),67-81.

[20] Ayuningtias, D., \&Khairunnisa. (2019). Faktor-Faktor Yang MenentukanPenerapan Internet Financial Reporting (StudiKasusPada Perusahaan SektorPertambangan yang terdaftar di Bursa Efek Indonesia (BEI) Tahun 2013-2017). E-Proceeding of Management :, 6(3), 5678-5686.

[21] Ginting, W. A. (2018). RegresiLogistikDalamMenganalisisFaktor- Faktor Yang MempengaruhiPelaporanKeuanganMelalui Internet. Riset\&JurnalAkuntansi, 2(2), 62-72.

[22] Siahaan, Audrey M., et.al. (2020).Analysis Of Full Time Driver Grab Income Comparison And City Minimum Wage (Case Study In Medan City). International Journal of Science and Management Studies; Volume 3 Issue 6, pp 